\title{
Analysis of Well Water Quality based on Physics, Chemical, and Microbiology Parameters in IAIN Tulungagung Area
}

\section{*Tutik Sri Wahyuni \& Desi Kartikasari}

Tadris Kimia/FTIK- Institut Agama Islam Negeri (IAIN) Tulungagung, Tulungagung - Indonesia 66221

Received 28 September 2020, Revised 26 October 2020, Accepted 24 November 2020

doi: 10.22487/j24775185.2020.v9.i4.pp245-250

\begin{abstract}
Water as a natural resource is needed in life. Nowadays, the need for freshwater is increasing. Meanwhile, most people fulfill their daily water needs from well water. This study aims to determine the quality of well water in the IAIN Tulungagung campus area based on physical, chemical, and biological parameters. This type of research is a quantitative descriptive. A total of 12 points from 4 stations were chosen by random sampling. Laboratory test results were compared with PerMenKes RI No. 492/MENKES/PER/IVI2010 and PerMenKes RI No. 32 Tahun 2017. The results of the study show that (1) two sources of water do not qualify as clean water based on physical parameters because the turbidity value and total dissolved solids (TDS) exceeds the quality standard, (2) five sources of water do not qualify as water clean based on chemical parameters because the Fe content exceeds the quality standard andlor low dissolved oxygen (DO) concentration, and (3) four wells do not meet bacteriological tests for the amount of coli fecal bacteria and total coliform. Well water in the IAIN campus area has decreased water quality caused by domestic waste.
\end{abstract}

Keywords: Quality, well water, physics, chemistry, microbiology

\section{Pendahuluan}

Air merupakan suatu senyawa yang tersusun dari atom $\mathrm{H}$ (hidrogen) dan atom $\mathrm{O}$ (oksigen) dengan rumus molekul H2O. Air sebagai sumber daya alam yang sangat penting dan mutlak dibutuhkan dalam kehidupan. Semua makhluk hidup, baik manusia, hewan maupun tumbuhan membutuhkan air. Air merupakan penyusun utama dalam tubuh makhluk hidup. Sekitar $60-70 \%$ dari tubuh manusia, tersusun dari air. Air berfungsi sebagai media pelarut berbagai zat dan membantu dalam proses metabolisme dalam tubuh makhluk hidup. Selain itu, air juga berperan sebagai media transportasi nutrisi. Bagi manusia, air memiliki peranan penting bagi kehidupan, yaitu untuk memenuhi kebutuhan masak dan minum, mandi, mencuci, mengairi tanaman, untuk keperluan industri, rekreasi, dan sebagainya.

Pemerintah telah menetapkan peraturan yang menjelaskan parameter kualitas air sesuai baku mutunya yang digunakan sebagai pedoman dalam pemanfaatan air untuk berbagai kebutuhan. Setiap kegiatan tertentu memiliki baku mutu yang berbeda sesuai dengan Peraturan Pemerintah Republik Indonesia Nomor 82 Tahun 2001 tentang Pengelolaan Kualitas Air dan Pengendalian Pencemaran Air. Berdasarkan klasifikasi mutu air, air digolongkan menjadi 4 kelas. Kelas air adalah peringkat kualitas air yang dinilai masih layak untuk dimanfaatkan bagi peruntukan tertentu. Kelas satu digunakan untuk air baku air minum; kelas dua digunakan untuk prasarana/sarana rekreasi air, pembudidayaan ikan air tawar, peternakan, air untuk mengairi pertanaman; kelas tiga digunakan untuk pembudidayaan ikan air tawar, peternakan, air untuk mengairi pertanaman, dan kelas empat yang digunakan untuk mengairi pertanaman dan atau peruntukan lain yang mempersyaratkan mutu air yang sama dengan kegunaan tersebut.

Salah satu sumber air yang sering dimanfaatkan oleh masyarakat adalah air sumur. Air sumur merupakan jenis air tanah, yaitu air yang terdapat di bawah permukaan tanah yang menempati zona jenuh air dengan tekanan hidrostatis sama atau lebih besar daripada tekanan udara (Todd, 1980). Air dapat ditemukan pada akuifer yaitu formasi batuan yang dapat menyimpan dan meloloskan air dalam jumlah yang cukup (Musa, dkk., 2019). Air sumur merupakan salah satu jenis dari air tanah yang berasal dari sebagian air hujan yang mencapai permukaan bumi dan terserap ke dalam tanah. Air tanah tersimpan di dalam lapisan batuan yang mengalami pengisian atau penambahan secara terus-menerus oleh alam (Suryana, 2013). Air sumur sering juga disebut dengan air tanah dangkal yang terdapat pada kedalaman sekitar 15 meter. Kualitas air sumur satu tempat dengan yang lain berbeda-beda dan kuantitasnya juga dipengaruhi oleh musim.

*Correspondence:

Tutik Sri Wahyuni

e-mail: tswahyuni@gmail.com

(c) 2020 the Author(s) retain the copyright of this article. This article is published under the terms of the Creative Commons Attribution License 4.0, which permits unrestricted non-commercial use, distribution, and reproduction in any medium, provided the original work is properly cited. 
Air sumur menjadi sumber utama masyarakat dalam memenuhi kebutuhan hidupnya sehari-hari karena selain cukup mudah didapatkan juga tergolong murah. Ini berlaku pada daerahdaerah yang sumber air tanahnya cukup mudah didapatkan. Namun, seiring bertambahnya jumlah penduduk dan aktivitas manusia yang kurang memperhatikan aspek ekologi seperti kebiasaan membuang sampah tidak pada tempatnya dan pembuangan limbah berbahaya, dapat mengakibatkan penurunan kuantitas dan kualitas air. Lebih lanjut, keterbatasan ketersediaan air untuk memenuhi kebutuhan manusia dapat menjadi permasalahan di masyarakat.

Ketersediaan air bersih berhubungan dengan dinamika kependudukan di suatu wilayah (Hunter, 2011; Alihar, 2018). Dalam pengelolaan sumberdaya air, saat ini perlu diperhatikan permasalahan penurunan kualitas air di beberapa daerah terutama di area perkotaan. Tingkat pertumbuhan dan kepadatan penduduk yang tinggi dapat berimplikasi terhadap akses untuk memperoleh air bersih (Alihar, 2018). Salah satu kota di Jawa Timur yang tengah berkembang saat ini yaitu Kabupaten Tulungagung. Dengan adanya beberapa perguruan tinggi, salah satunya IAIN Tulungagung yang berada di Desa Plosokandang dan perkembangan sektor industri dan perdagangan, mengakibatkan peningkatan jumlah pendatang di Kabupaten Tulungagung. Menurut data Badan Pusat Statistik Kabupaten Tulungagung pada tahun 2018, jumlah penduduk Desa Plosokandang Kecamatan Kedungwaru Kabupaten Tulungagung - Jawa Timur adalah 8.120 jiwa. Awal tahun akademik 2018-2019, peningkatan jumlah mahasiswa di IAIN Tulungagung mencapai kisaran 5.600 mahasiswa, sehingga jumlah mahasiswa secara keseluruhan mencapai lebih dari lima belas ribu mahasiswa yang sebagian berasal dari luar kota sehingga mereka harus tinggal di rumah kos atau kontrakan di area kampus. Selain mahasiswa, pendatang juga berasal dari kalangan pegawai/ karyawan dan masyarakat umum/ urban yang membuka usaha baru di area kampus. Fakta ini menunjukkan bahwa pertambahan jumlah penduduk di area kampus IAIN Tulungagung semakin pesat yang juga sebanding dengan kebutuhan air juga semakin besar.

Sebagian besar masyarakat di area kampus IAIN Tulungagung memenuhi kebutuhan air sehari-hari mereka dari air sumur. Sebagian masyarakat tersebut menggunakan air sumur sebagai air minum dan untuk memenuhi kebutuhan sehari-hari yang lain seperti masak dan mencuci. Meningkatnya jumlah penduduk akibat dari bertambahnya jumlah mahasiswa maupun pekerja yang menetap dalam waktu yang lama, tentu akan berpengaruh terhadap meningkatnya kebutuhan air bersih. Hal ini juga akan meningkatkan potensi tercemarnya sumber mata air karena meningkatnya limbah air yang dihasilkan dari aktivitas manusia.

Hasil pengamatan sementara, air di lokasi 3 (8004'41.7"S111055'43.5"E) berbau dan berwarna kekuningan, bahkan ketika menggunakan air tersebut, ada yang mengeluhkan terasa gatal-gatal pada kulit dan ruam-ruam kemerahan. Selain itu, yang menjadi permasalahan adalah masyarakat sekitar kurang bahkan tidak mengetahui apakah air sumur yang sering digunakan masih layak atau tidak untuk digunakan sebagai air minum. Oleh karena itu, penting untuk dilakukan pengujian untuk mengetahui kualitas air sumur rakyat di area kampus IAIN Tulungagung berdasarkan analisis beberapa parameter yaitu parameter fisika, kimia dan biologi. Parameter fisika meliputi warna, bau, rasa, suhu, kekeruhan (turbidimetri), dan residu terlarut (TDS). Parameter kimia terdiri dari $\mathrm{pH}$, kadar oksigen terlarut/dissolved oxygen (DO) dan kadar besi $(\mathrm{Fe})$. Parameter biologi dari uji mikrobiologi sampel air yang meliputi jumlah bakteri E. Coli dan total Coliform. Selanjutnya datadata tersebut dibandingkan dengan nilai baku mutu air berdasarkan Kriteria Mutu Air menurut PerMenKes RI No. 492/MENKES/PER/IV/2010 dan PerMenKes RI No. 32 Tahun 2017.

\section{Metode}

Jenis penelitian ini adalah penelitian deskriptif kuantitatif melalui uji laboratorium. Penentuan sampel penelitian dilakukan dengan teknik random sampling. Pengambilan sampel dilakukan di area kampus IAIN Tulungagung Desa Plosokandang Kecamatan Kedungwaru Kabupaten Tulungagung Provinsi Jawa Timur dengan jumlah 12 titik sampel (air sumur) (Tabel 1). Pengambilan sampel air sumur dilakukan dengan metode pengambilan sampel sesaat (grab sample). Sampel sesaat atau grab sample yaitu sampel yang diambil secara langsung dari sumber air sumur. Sampel tersebut hanya menggambarkan karakteristik air pada saat pengambilan sampel (Effendi, dkk., 2003; Ariani, 2018). Pengambilan sampel air dilakukan pada Bulan Agustus sampai dengan September 2019 pada pukul $08.00-12.00$ WIB.

Tabel 1. Rincian titik sampel penelitian

\begin{tabular}{|c|c|c|}
\hline No. & Titik Sampel & Titik koordinat \\
\hline 1 & Lokasi 1 & 8004 '54.5”S111055'46.2”E \\
\hline 2 & Lokasi 2 & 8004'36.7"S111055’31.9"E \\
\hline 3 & Lokasi 3 & 8004'41.7"S111055'43.5"E \\
\hline 4 & Lokasi 4 & 8004’48.5”S111055'51.5”E \\
\hline 5 & Lokasi 5 & 8004'38.1"S111055'40.0"E \\
\hline 6 & Lokasi 6 & 8004’38.9”S111055'40.6”E \\
\hline 7 & Lokasi 7 & 8004’41.3"S111055'55.5"E \\
\hline
\end{tabular}




\begin{tabular}{|c|c|c|}
\hline 8 & Lokasi 8 & 8004'34.7"S111055'25.1”E \\
\hline 9 & Lokasi 9 & 8004'48.6”S111055’46.4”E \\
\hline 10 & Lokasi 10 & 8004'34.3"S111055'26.6"E \\
\hline 11 & Lokasi 11 & 8004'27.6”S111055'56.8”E \\
\hline 12 & Lokasi 12 & 8004'35.3"S111055'23.8”E \\
\hline
\end{tabular}

Secara umum, prosedur penelitian ini terdiri dari kajian kepustakaan, orientasi lapangan, dan pengambilan sampel air sumur dari kran. sampel setiap lokasi diambil sampel air sekitar sebanyak $1500 \mathrm{~mL}$ dan diberi perlakuan tertentu agar suhu tetap konstan yang bertujuan agar sifat fisika, kimia dan biologi dari sampel tersebut dapat dipertahankan dan diawetkan. Parameter kualitas air dan metode analisisnya disajikan pada Tabel 2.

Tabel 2. Parameter kualitas air dan metode analisis

\begin{tabular}{ccc}
\hline No. & Parameter & Metode Analisis \\
\hline 1 & Warna & Metode visual (langsung) \\
2 & Bau & Metode langsung \\
3 & Rasa & Metode langsung \\
4 & Suhu & Dengan probe suhu (TI-15L 0584) \\
5 & Kekeruhan & Metode Turbidimeter \\
6 & TDS & TDS-meter (CON 450 Meter Kit, Serial No: 2643271) \\
7 & pH & Metode elektrometric dengan menggunakan pH meter (TI-15L 0584) \\
8 & Dissolved Oxygen (DO) & Metode Titrasi dengan metode Winkler \\
9 & Kadar Fe & Metode Spektrofotometri \\
10 & E. Coli & Metode Tabung/ Most Probable Number (MPN) \\
11 & Coliform & Metode Tabung/ Most Probable Number (MPN) \\
\hline
\end{tabular}

Data hasil pemeriksaan kualitas air di Laboratorium Kesehatan dan Laboratorium Dinas Lingkungan Hidup Kabupaten Tulungagung selanjutnya diolah dan disajikan dalam bentuk tabel dan narasi. Hasilnya dibandingkan dengan PerMenKes RI No. 492/MENKES/PER/IV/2010 DAN PerMenKes RI No. 32 Tahun 2017.

\section{Hasil dan Pembahasan}

Pengambilan sampel air sumur pada penelitian ini mengacu pada SNI 06-2412-1991. Hasil uji kualitas air sumur di area kampus IAIN Tulungagung berdasarkan parameter fisika, kimia, dan biologi dipaparkan sebagai berikut.

\section{Hasil Uji Parameter Fisika}

Hasil uji parameter fisika untuk analisis kualitas air sumur rakyat di area kampus IAIN Tulungagung dapat dibaca pada Tabel 3 .
Berdasarkan hasil uji kualitas air di area kampus IAIN Tulungagung ditinjau dari parameter fisika, dapat diketahui bahwa sebagian besar air sumur tersebut memenuhi syarat sebagai air bersih. Hasil uji parameter fisika di lokasi 3 memiliki dua parameter yang tidak memenuhi syarat, yaitu warna air keruh dan dibuktikan dengan nilai kekeruhan yang diukur dengan menggunakan turbidimeter juga melebihi baku mutu. Hasil yang lain yang perlu menjadi titik amatan yaitu air sumur di lokasi 9 memiliki total padatan terlarut/total dissolved solid (TDS) yang melebihi baku mutu. Padatan terlarut tersebut dapat berasal dari ion-ion anorganik. Semakin tinggi TDS yang melebihi baku mutu juga menunjukkan pencemaran air. $\mathrm{Hal}$ ini menunjukkan bahwa kedua sumber air tersebut tidak memenuhi syarat sebagai air bersih ditinjau dari parameter fisika.

Tabel 3. Hasil Uji Parameter Fisika

\begin{tabular}{cccccccc}
\hline No. & Sampel & Warna & Bau & Rasa & $\begin{array}{c}\text { Suhu } \\
\left({ }^{\circ} \mathrm{C}\right)\end{array}$ & $\begin{array}{c}\text { Kekeruhan } \\
(\mathrm{NTU})\end{array}$ & $\begin{array}{c}\text { TDS } \\
\text { (Total Zat Padat Terlarut) }\end{array}$ \\
\hline \multicolumn{2}{c}{ Baku Mutu } & TW & TB & TR & Suhu udara $\pm 3\left({ }^{\circ} \mathrm{C}\right)$ & 5 & $500 \mathrm{mg} / \mathrm{l}(\mathrm{ppm})$ \\
1 & L1 & TW & TB & TR & $31,8 / 29$ & 0,95 & 183,4 \\
2 & L2 & TW & TB & TR & $28,4 / 29$ & 0,45 & 365,1 \\
3 & L3 & Keruh & TB & Agak asin & $25,7 / 29$ & 10,09 & 302,7 \\
4 & L4 & TB & TW & TB & $28,4 / 29$ & 6,59 & 243,4 \\
5 & L5 & TW & TB & TR & $28,2 / 30$ & 0,10 & 300,5 \\
6 & L6 & TW & TB & TR & $28,6 / 30$ & 0,89 & 261,8 \\
7 & L7 & TW & TB & TR & $33 / 30$ & 0,06 & 320,3 \\
8 & L8 & TW & TB & Agak asam & $27,2 / 30$ & 0,14 & 277,1 \\
9 & L9 & TW & TB & TR & $28,1 / 29$ & 0,03 & 581,5 \\
10 & L10 & TW & TB & TR & $29,8 / 32$ & 0,33 & 297,1 \\
11 & L11 & TW & TB & TR & $32,8 / 30$ & 1,73 & 284,2 \\
12 & L12 & TW & TB & TR & $30,5 / 30$ & 0,82 & 332,5 \\
\hline
\end{tabular}




\section{Hasil uji parameter kimia}

Hasil uji parameter kimia untuk analisis kualitas air sumur rakyat di area kampus IAIN Tulungagung dapat dibaca pada Tabel 4.

Tabel 4. Hasil Uji Parameter Kimia

\begin{tabular}{|c|c|c|c|c|}
\hline No. & Sampel & $\mathrm{pH}$ & Oksigen Terlarut/ DO & Kadar Fe \\
\hline \multicolumn{2}{|c|}{ Baku Mutu } & $5-9$ & $\geq 4(\mathrm{ppm})$ & $0,3 \mathrm{mg} / \mathrm{l}(\mathrm{ppm})$ \\
\hline 1 & L1 & 6,92 & 5,67 & 0,05 \\
\hline 2 & L2 & 5,29 & 5,82 & 0,02 \\
\hline 3 & L3 & 6,96 & 3,18 & 1,91 \\
\hline 4 & L4 & 7,60 & 4,59 & 0,66 \\
\hline 5 & L5 & 6,82 & 2,83 & 0,06 \\
\hline 6 & L6 & 6,82 & 4,19 & 0,11 \\
\hline 7 & L7 & 6,71 & 4,23 & 0,09 \\
\hline 8 & L8 & 6,78 & 4,19 & $<0,03$ \\
\hline 9 & L9 & 6,46 & 5,11 & 0,04 \\
\hline 10 & L10 & 7,00 & 4,99 & 1,08 \\
\hline 11 & L11 & 6,61 & 3,43 & 0,20 \\
\hline 12 & L12 & 6,82 & 4,11 & $<0,03$ \\
\hline
\end{tabular}

Berdasarkan hasil analisis kualitas air sumur rakyat di area kampus IAIN Tulungagung berdasarkan parameter kimia yang meliputi $\mathrm{pH}$, konsentrasi oksigen terlarut/ DO, dan kadar besi $(\mathrm{Fe})$ dapat diketahui bahwa terdapat 7 (tujuh) air sumur yang memenuhi syarat sebagai air bersih. Titik-titik sampel yang tidak memenuhi parameter kimia antara lain lokasi lokasi 3, 5, dan 11 yang disebabkan oleh konsentrasi oksigen terlarut (DO) yang rendah, serta lokasi 3, 4, dan 10 yang disebabkan oleh kadar Fe yang melebihi baku mutu.

Dissolved oxygen (DO) adalah banyaknya oksigen terlarut dalam satuan mg dalam satu liter air atau dapat dinyatakan dengan satuan $\mathrm{mg} / \mathrm{L}$ atau ppm. Konsentrasi oksigen terlarut di dalam air dipengaruhi oleh suhu dan tekanan udara. Semakin rendah nilai DO, semakin tinggi tingkat pencemaran. Patil \& Patil (2011) dalam penelitiannya juga menemukan 3 (tiga) titik sampel air sumur di Kota Amalner, India yang memiliki DO rendah sehingga menunjukkan terkontaminasi berat yang disebabkan oleh materi organik.

Salah satu unsur logam yang bersifat mudah larut dalam air adalah zat besi, yang terdapat dalam bentuk ion $\mathrm{Fe}^{2+}$. Besi sebagai ion $\mathrm{Fe}^{2+}$ di dalam air tanah terbentuk di daerah yang kekurangan oksigen (Manik, 2016). Lebih lanjut dijelaskan bahwa dalam keadaan aerobik, umumnya besi berada dalam bentuk $\mathrm{Fe}^{3+}$ atau bahan organik kompleks. oksigen yang terlarut di dalam air tanah berasal dari perombakan bahan-bahan organik oleh mikroba dan tidak berasal dari atmosfer. Keberadaan zat besi yang melebihi ambang batas dapat menyebabkan air menjadi tidak layak untuk keperluan rumah tangga seperti rasa air tidak enak, menyebabkan berkas karat pada pakaian, peralatan rumah tangga, keramik dan lain-lain.

\section{Hasil Uji Parameter Biologi}

Hasil uji parameter biologi/uji bakteriologis dilakukan di laboratorium Kesehatan
Dinas Kesehatan Kabupaten Tulungagung. Hasil uji bakteriologis untuk analisis kualitas air sumur rakyat di area kampus IAIN Tulungagung dapat dibaca pada Tabel 5.

Berdasarkan data uji bakteriologis dapat diketahui bahwa 5 (lima) sampel air sumur yang memenuhi syarat sebagai air bersih terhadap jumlah bakteri Coli Tinja dan 6 (enam) dari sampel air sumur yang memenuhi syarat sebagai air bersih terhadap total Coliform. Air sumur memenuhi kedua parameter uji bakteriologis adalah lokasi 1, 4, 7, dan 11, sedangkan air sumur yang tidak memenuhi kedua parameter uji bakteriologis adalah lokasi 2, 5, 6, 8, dan 12. Keempat titik sampel tersebut berada pada pemukiman padat penduduk dan jarak antara air sumur dan septictank sangat dekat, sekitar 3 meter. Hal ini dapat mengakibatkan air limbah dari septictank merembes melalui celahcelah batuan dan pori-pori tanah sehingga masuk ke dalam air sumur dan menyebabkan kontaminasi bakteri. Air yang mengandung Coliform tinja berarti air tersebut telah tercemar oleh tinja (Waluyo, 2013). Penularan penyakit dapat berhubungan dengan air yang mengandung coliform tinja, seperti penyakit diare. Musa, dkk. (2019) dalam penelitiannya menyatakan hasil analisis parameter fisik, parameter kimia dan parameter biologi air tanah bebas di Kota Mataram menunjukan bahwa air telah tercemar.Terdapat beberapa parameter air yang telah melampaui batas maksimum di beberapa titik sampel, yaitu daya hantar listrik (DHL), TDS, dan bakteri Coliform. Air Sumur di Dagon Dawa, Nigeria juga terkontaminasi berat oleh bakteri Coliform dalam jumlah $26.20-19.00 \times 102 \mathrm{cfu} / \mathrm{mL}$ (Auta, dkk., 2017). Bambang (2014) menyatakan bahwa air yang telah terkontaminasi kotoran manusia yang mengandung Shigella $s p$ dan Escherichia coli dapat menyebabkan gejala diare, deman, kram perut, dan muntah-muntah. Fakta tersebut harus diwaspadai sehingga diharapkan 
masyarakat memiliki kesadaran terhadap sanitasi lingkungan.

Tabel 5. Hasil Uji Bakteriologis

\begin{tabular}{|c|c|c|c|c|c|c|c|c|}
\hline \multirow{2}{*}{ No. } & \multirow{2}{*}{ Sampel } & \multicolumn{3}{|c|}{ Tes perkiraan } & \multicolumn{2}{|c|}{ Tes Penegasan } & \multicolumn{2}{|c|}{ MPN/100mL } \\
\hline & & $10 \mathrm{~mL}$ & $1 \mathrm{~mL}$ & $0.1 \mathrm{~mL}$ & Coliform & Coli tinja & Coliform & Coli tinja \\
\hline \multirow{2}{*}{1} & \multirow{2}{*}{ L1 } & $5 / 4$ & $1 / 0$ & $1 / 0$ & - & 0.0 .0 & - & 0 \\
\hline & & $5 / 4$ & $1 / 0$ & $1 / 0$ & 4.0 .0 & - & 15 & - \\
\hline \multirow{2}{*}{2} & \multirow{2}{*}{ L2 } & $5 / 5$ & $1 / 1$ & $1 / 0$ & - & 5.0 .0 & - & 3,8 \\
\hline & & $5 / 5$ & $1 / 1$ & $1 / 0$ & 5.1 .0 & - & 96 & - \\
\hline \multirow{2}{*}{3} & \multirow{2}{*}{ L3 } & $5 / 5$ & $1 / 0$ & $1 / 1$ & - & 0.0 .0 & - & 0 \\
\hline & & $5 / 5$ & $1 / 0$ & $1 / 1$ & 5.0 .1 & - & 96 & - \\
\hline \multirow{2}{*}{4} & \multirow{2}{*}{ L4 } & $5 / 5$ & $1 / 0$ & $1 / 1$ & - & 0.0 .0 & - & 0 \\
\hline & & $5 / 5$ & $1 / 0$ & $1 / 1$ & 2.0 .1 & - & 7,5 & - \\
\hline \multirow{2}{*}{5} & \multirow{2}{*}{ L5 } & $5 / 5$ & $1 / 0$ & $1 / 1$ & - & 5.0 .1 & - & 96 \\
\hline & & $5 / 5$ & $1 / 0$ & $1 / 1$ & 5.0 .1 & - & 96 & - \\
\hline \multirow{2}{*}{6} & \multirow{2}{*}{ L6 } & $5 / 5$ & $1 / 1$ & $1 / 1$ & - & 5.1 .1 & - & $240+$ \\
\hline & & $5 / 5$ & $1 / 1$ & $1 / 1$ & 5.1 .1 & - & $240+$ & - \\
\hline \multirow{2}{*}{7} & \multirow{2}{*}{ L7 } & $5 / 2$ & $1 / 0$ & $1 / 0$ & 2.0 .0 & - & 5 & - \\
\hline & & $5 / 2$ & $1 / 0$ & $1 / 0$ & - & 0.0 .0 & - & 0 \\
\hline \multirow{2}{*}{8} & \multirow{2}{*}{ L8 } & $5 / 5$ & $1 / 1$ & $1 / 1$ & - & 5.1 .1 & - & $240+$ \\
\hline & & $5 / 5$ & $1 / 1$ & $1 / 1$ & - & 5.1 .1 & $240+$ & - \\
\hline \multirow{2}{*}{9} & \multirow{2}{*}{ L9 } & $5 / 1$ & $1 / 0$ & $1 / 1$ & 1.0 .1 & - & 4,4 & - \\
\hline & & $5 / 1$ & $1 / 0$ & $1 / 1$ & - & 1.0 .0 & - & 2,1 \\
\hline \multirow{2}{*}{10} & \multirow{2}{*}{ L10 } & $5 / 3$ & $1 / 1$ & $1 / 0$ & 3.1 .0 & - & 12 & - \\
\hline & & $5 / 3$ & $1 / 1$ & $1 / 0$ & - & 1.0 .0 & - & 2,2 \\
\hline \multirow{2}{*}{11} & \multirow{2}{*}{ L11 } & $5 / 2$ & $1 / 0$ & $1 / 0$ & 2.0 .0 & - & 5 & - \\
\hline & & $5 / 2$ & $1 / 0$ & $1 / 0$ & - & 0.0 .0 & - & 0 \\
\hline \multirow{2}{*}{12} & \multirow{2}{*}{ L12 } & $5 / 5$ & $1 / 1$ & $1 / 1$ & 5.1 .1 & & $240+$ & - \\
\hline & & $5 / 5$ & $1 / 1$ & $1 / 1$ & - & 5.1 .1 & - & $240+$ \\
\hline
\end{tabular}

Keterangan:

Batas maksimum PerMenKes RI No. 492/MENKES/PER/IV/2010

Batas maksimum syarat PerMenKes RI No. 32 Tahun 2017

Air Minum MPN/100 ml : 0

Air Minum MPN/100 ml : 50

E.Coli air bersih/ $100 \mathrm{ml} \quad: 0$

E. Coli air kolam renang : $<1$

Berdasarkan hasil analisis kualitas air dari 12 titik sampel di area kampus IAIN Tulungagung yang meliputi rumah warga, kos, asrama, maupun pondok pesantren, dapat disimpulkan bahwa ada 2 (dua) titik sampel yang memenuhi baku mutu kualitas air bersih (air minum) karena memenuhi ketiga parameter uji, baik parameter fisika, kimia maupun biologi yaitu air sumur di lokasi 1 dan lokasi 7. Kedua kos tersebut memiliki karakteristik yang hampir sama, meskipun posisinya berbeda. Jika ditinjau dari posisi, lokasi 1 terletak di sebelah selatan kampus IAIN Tulungagung, sedangkan lokasi 7 berada di sebelah timur kampus, dengan jarak sekitar $1,5 \mathrm{~km}$ dari kampus. Di sekitarnya ada lahan pertanian yang ditanami tanaman tebu dan pepohonan yang masih rindang, begitu pula keberadaan rumah juga tidak terlalu padat, jumlah penghuni kos juga relatif sedikit.

Dengan demikian, penurunan kualitas air di area kampus IAIN Tulungagung disebabkan oleh limbah domestik yang dihasilkan oleh aktivitas dalam kehidupan sehari-hari. selain itu, sebagian air sumur memiliki jarak yang relatif dekat dengan septictank, yaitu sekitar 3-5 meter. Hal ini juga menyebabkan air limbah masuk ke dalam pori-pori tanah dan merembes masuk ke dalam air sumur yang dapat menyebabkan pencemaran air.
Waluyo (2013) menjelaskan penanggulangan pencemaran air yang diakibatkan oleh limbah domestik dan kegiatan lainnya dapat dicegah dan ditanggulangi dengan cara:

a. Dilakukan pengurasan septictank secara berkala.

b. Mengumpulkan limbah bahan padat domestik (seperti tinja) dan memanfaatkannya untuk keperluan lain, misalnya dibuat pupuk kompos.

c. Masyarakat hendaknya meneladani prinsip bahwa dirinya sebagai bagian dari ekosistem sehingga peduli terhadap pelestarian fungsi lingkungan dan pengelolaan sumber daya alam secara bijaksana.

d. Masyarakat memperhatikan sumber-sumber pencemaran air yang dapat berasal dari limbah domestik, sampah organik, bahan-bahan kimia, seperti pupuk, pestisida.

e. Sumber air seperti sumur harus memiliki tempat (lokasi) dan konstruksi yang terlindung dari drainase permukaan dan banjir. Peternakan hewan-hewan harus juga cukup jauh dari sumber air.

Sarana air bersih, salah satunya bersumber dari air sumur harus dilindungi. Salah satu kurang baiknya sarana air bersih karena tidak terlindung 
dari pencemaran. Bila sarana air bersih tersebut memenuhi persyaratan kesehatan, maka diharapkan pencemaran dapat dikurangi sehingga diperoleh air berkualitas baik. Menteri Kesehatan RI juga menyarankan dalam menentukan air bersih sebagai air yang dapat dipergunakan untuk keperluan sehari-hari yang kualitasnya memenuhi kesehatan dan dapat diminum jika telah dimasak.

\section{Kesimpulan}

Hasil uji kualitas air di area kampus IAIN Tulungagung ditinjau dari parameter fisika, dapat disimpulkan bahwa sebagian besar air sumur memenuhi syarat sebagai air bersih. Namun, air sumur di lokasi 3 memiliki nilai kekeruhan melebihi baku mutu dan air sumur di lokasi 9 memiliki nilai TDS yang melebihi baku mutu.

Hasil uji kualitas air di area kampus IAIN Tulungagung ditinjau dari parameter kimia, dapat disimpulkan bahwa terdapat 7 (tujuh) air sumur yang memenuhi syarat sebagai air bersih. Titik-titik sampel yang tidak memenuhi parameter kimia antara lain lokasi lokasi 3, 5, dan 11 yang disebabkan oleh konsentrasi oksigen terlarut (DO) yang rendah, serta lokasi 3, 4, dan 10 yang disebabkan oleh kadar Fe yang melebihi baku mutu.

Hasil uji kualitas air di area kampus IAIN Tulungagung ditinjau dari parameter biologi, dapat disimpulkan bahwa ada 4 (empat) sampel air sumur yang memenuhi syarat sebagai air bersih terhadap jumlah bakteri Coli Tinja dan total Coliform, yaitu lokasi 1, 4, 7, dan 11, sedangkan air sumur yang tidak memenuhi kedua parameter uji bakteriologis adalah lokasi 2, 5, 6, 8, dan 12. Keempat titik sampel tersebut berada pada pemukiman padat penduduk dan jarak antara air sumur dan septictank sangat dekat, sekitar 3 meter. Hal ini dapat mengakibatkan air limbah dari septictank merembes melalui celah-celah batuan dan pori-pori tanah sehingga masuk ke dalam air sumur dan menyebabkan kontaminasi bakteri. Air sumur di area kampus IAIN Tulungagung mengalami penurunan kualitas air yang diakibatkan oleh limbah domestik.

\section{Ucapan Terima Kasih}

Penulis mengucapkan terimakasih kepada semua pihak-pihak yang telah membantu penulis sehingga penelitian ini berjalan dengan baik dan lancar.

\section{Referensi}

Alihar, F. (2018). Penduduk dan akses air bersih di kota semarang. Jurnal Kependudukan Indonesia, 13(1), 67-76.
Ariani, F., Puspitasari, R. L., \& Priambodo, T. W. (2018). Pencemaran coliform pada air sumur di sekitar sungai ciliwung. Jurnal Al-Azhar Indonesia Seri Sains dan Teknologi, 4(3), 149155.

Auta, K. I., Mohammed, S. S. D. \& Abubakar, M. I. (2017). Assessment of bacteriological quality of well water around dogon dawa district in birnin gwari local government, kaduna state. Science World Journal, 12(4), 38-42.

Bambang, Adrian. G. (2014). Analisis cemaran bakteri coliform dan identifikasi escherichia coli pada air isi ulang dari depot di kota manado. Jurnal Ilmiah Farmasi, 3(3), 325-334.

Effendi. (2003). Telaah kualitas air. Yogyakarta: Kanisius.

Hunter, L. (2001). Population and environment: a complex relationship in population matters. research brief. santa monica, California: RAND Corporation. Diakses dari http//www.rand.org/pubs/researchbrief/RB504index1.html.

Manik. 2016. Pengelolaan lingkungan hidup. Jakarta: Kharisma Putra Grafika.

Musa, L., Purnama, S. \& Suprayogi, S. (2019). Analisis kerentanan dan kualitas airtanah bebas di kota mataram. Jurnal Sains Informasi Geografi, 2(1), 1-8.

Patil, V, T. \& Patil, P. R. (2011). Groundwater quality of open wells and tube welss around amalner town of jalgaon district, maharashtra, india. E-Journal of Chemistry, 8(1), 53-58.

Peraturan Menteri Kesehatan RI No. 492/MENKES/PER/IV/2010 tentang Persyaratan Kualitas Air Minum.

PerMenKes RI No. 32 Tahun 2017 tentang Standar Baku Mutu Kesehatan Lingkungan dan Persyaratan Kesehatan Air untuk Keperluan Higiene Sanitasi, Kolam Renang, Solus Per Aqua, dan Pemandian Umum.

Peraturan Pemerintah Republik Indonesia Nomor 82 Tahun 2001 tentang Pengelolaan Kualitas Air dan Pengendalian Pencemaran Air.

Suryana. (2013). Analisis kualitas air sumur dangkal di kecamatan biringkanayya kota Makassar. Makassar: Universitas Hasanuddin.

Todd. D. K. (1980). Ground water hydrology. University of California. Berkeley: John Wiley $\&$ Sons Inc,USA.

Waluyo, L., 2013. Mikrobiologi lingkungan. Malang: UMM Press. 